\title{
Effects of Sodium Chloride on Commercial Asparagus and of Alternative Forms of Chloride Salt on Fusarium Crown and Root Rot
}

\author{
T. C. Reid, Graduate Research Assistant, M. K. Hausbeck, Associate Professor, Department of Plant Pathology, \\ and K. Kizilkaya, Statistical Consultant, College of Agricultural and Natural Resources Statistical Consulting Ser- \\ vice, Michigan State University, East Lansing 48824
}

\begin{abstract}
Reid, T. C., Hausbeck, M. K., and Kizilkaya, K. 2001. Effects of sodium chloride on commercial asparagus and of alternative forms of chloride salt on Fusarium crown and root rot. Plant Dis. 85:1271-1275.

Experiments with applications of $\mathrm{NaCl}(560$ and $1,120 \mathrm{~kg} / \mathrm{ha})$ and lime $(6,719 \mathrm{~kg} / \mathrm{ha})$ were conducted in asparagus fields in commercial production (one healthy and one exhibiting symptoms of early decline), and an experiment with $\mathrm{NaCl}(1,120 \mathrm{~kg} / \mathrm{ha})$ was conducted in a badly declined research field at Michigan State University from 1998 to 2000 to determine whether these treatments control Fusarium crown and root rot of asparagus. Growth chamber and greenhouse studies were conducted to test the ability of alternative forms $\left(\mathrm{CaCl}_{2}, \mathrm{NH}_{4} \mathrm{Cl}\right.$, and $\left.\mathrm{MnCl}_{2}\right)$ of chloride salt to reduce disease caused by $F$. oxysporum f. sp. asparagi and $F$. proliferatum. $\mathrm{NaCl}$ applications increased yield and fern health in the research plot, but not in commercial fields. Soil tests in these fields indicated that $\mathrm{NaCl}$ did not decrease levels of calcium, magnesium, or potassium, and did not affect $\mathrm{pH}$. In growth chamber studies with asparagus seedlings in Hoagland's agar test tubes, and in greenhouse studies with asparagus seedlings in soil, none of the alternative forms of chloride salt tested were more effective than $\mathrm{NaCl}$ in controlling Fusarium crown and root rot.
\end{abstract}

Fusarium crown and root rot, caused by Fusarium proliferatum (T. Matsushima) Nirenberg and Fusarium oxysporum (Schlechtend.) f. sp. asparagi (Cohen \& Heald), is the major cause of asparagus early decline, an economically important disease worldwide. Symptoms of the disease include yellowing and senescence of ferns, destruction of feeder roots, collapse of storage roots, and death of crowns (13). In a perennial crop such as asparagus, the lack of effective chemical controls (20) and the limited resistance of available cultivars (21) makes Fusarium crown and root rot a difficult disease to control.

The use of sodium chloride $(\mathrm{NaCl})$ as a soil amendment has shown promise as a disease management strategy. Asparagus is an extremely salt tolerant crop, and salt applications were recommended by gardening experts until the early part of this century $(2,4,15)$. Elmer $(8,11)$ demonstrated a reduction in Fusarium crown and root rot with $\mathrm{NaCl}$ applications in the greenhouse and in small research field plots, and some commercial asparagus growers have adopted the practice.

Corresponding author: M. K. Hausbeck

E-mail: hausbec1@pilot.msu.edu

Accepted for publication 6 September 2001.

Publication no. D-2001-1017-01R

(C) 2001 The American Phytopathological Society
Salt applications on field soils can potentially cause a loss of soil structure, soil acidification, nutrient displacement, groundwater contamination, and damage to sensitive rotation crops (3). Although the mechanism by which $\mathrm{NaCl}$ suppresses disease is not clearly understood, it is likely that the chloride molecule is playing a role $(8,11)$. Research has suggested that potassium chloride $(\mathrm{KCl})$ is not as effective as $\mathrm{NaCl}$ in disease suppression (11), but the effects of other forms of chloride salt on disease have never been studied.

Increasing $\mathrm{pH}$ decreases the severity of Fusarium diseases in some crops, including cotton (1) and tomato (19). Hodupp (16) has demonstrated an increase in asparagus yields at $\mathrm{pH} 7.5$, and soil $\mathrm{pH}$ can affect the availability of nutrients to the plant, which can be a factor in Fusarium disease suppression $(17,18)$.

The purpose of this study was to determine the effects of yearly lime and $\mathrm{NaCl}$ applications on the yield and fern vigor of both declining and healthy commercial asparagus plantings in Michigan; to determine the effect of $\mathrm{NaCl}$ on a badly declined asparagus research planting; to determine the effect of soil treatments on $\mathrm{pH}$ and the quantity of sodium, magnesium, potassium, and calcium in the soil; and to determine whether alternative forms of chloride salt are as effective as $\mathrm{NaCl}$ in disease suppression.

\section{MATERIALS AND METHODS}

Growth chamber experiments with chloride salts. Growth chamber studies were conducted to test whether different forms of chloride salt suppress disease caused by $F$. oxysporum f. sp. asparagi and $F$. proliferatum. In tests with $F$. oxysporum f. sp. asparagi, treatments consisted of the following: (i) a control (no salt added), (ii) a low rate of $\mathrm{NaCl}(17.1 \mathrm{mM})$, (iii) a high rate of $\mathrm{NaCl}(34.2 \mathrm{mM})$, (iv) $\mathrm{CaCl}_{2}$ (17.1 $\mathrm{mM}$ ), and (v) $\mathrm{NH}_{4} \mathrm{Cl}(34.2 \mathrm{mM})$. For tests with $F$. proliferatum, the same treatments were used with the addition of $\mathrm{MnCl}_{2}(8.55$ $\mathrm{mM})$. The low rate of $\mathrm{NaCl}(17.1 \mathrm{mM})$ was excluded from these tests. Hoagland's solution agar $(6,7)$ was prepared and chloride salt added to provide an equal amount of chloride to each treatment except the control, the low rate of $\mathrm{NaCl}$, and the $\mathrm{MnCl}_{2}$ treatment. The rate of $\mathrm{MnCl}_{2}$ was reduced because the full rate was toxic to the plants. All treatments were standardized to $\mathrm{pH} 6.0$ using sodium hydroxide $(\mathrm{NaOH})$. The amount of agar (12 to 16 $\mathrm{g} /$ liter) added to each treatment was varied in order to achieve a relatively uniform consistency for root growth with each treatment. Each solution was autoclaved and added aseptically to sterile glass test tubes $(16 \times 150 \mathrm{~mm})$.

Asparagus seeds (cv. Mary Washington, Rupp Seeds, Wauseon, OH) were sterilized according to the method of Damicone et al. (5) by spinning on a magnetic stir plate for $24 \mathrm{~h}$ in a mixture of $100 \mathrm{ml}$ of acetone and $2.5 \mathrm{~g}$ of benomyl ( $5 \mathrm{~g}$ of Benlate WP, E. I. du Pont de Nemours \& Co., Wilmington, $\mathrm{DE})$, rinsing them in acetone $(3 x)$ and in distilled water $(3 \mathrm{x})$, then spinning for $1 \mathrm{~h}$ in $1.05 \%$ sodium hypochlorite $(20 \%$ household bleach) and rinsing again in sterile distilled water $(3 \times)$. Seeds were airdried and placed on water agar under sterile conditions. Once hypocotyls began to emerge, healthy, uniform seedlings were transferred to the test tubes under sterile conditions. Tubes were capped, and seedlings were grown for 10 days. Twenty and 40 seedlings were used for each treatment in tests with $F$. oxysporum f. sp. asparagi and $F$. proliferatum, respectively.

Cultures of $F$. oxysporum f. sp. asparagi and $F$. proliferatum used in this study were isolated from diseased asparagus crowns, stems, and soil in three commercial asparagus fields in Oceana County, MI, and a research plot at the Michigan State University Plant Pathology Farm, and stored on silica gel as described by Windels et al. (23). Isolates of F. oxysporum f. sp. aspar- 
agi (isolate 2-7) and $F$. proliferatum (isolate P-67), which have been shown to be highly virulent on asparagus seedlings ( $\mathrm{T}$. C. Reid, M. K. Hausbeck, and K. Kizilkaya, unpublished), were grown on carnation leaf agar for 2 weeks under fluorescent lights. The plates were flooded with sterile distilled water, scraped with a scalpel to loosen spores, filtered through three layers of sterile cheesecloth, counted using a hemacytometer, and diluted with sterile water to $1 \times 10^{6}$ conidia per milliliter. Onehalf milliliter of the spore suspension was added to each seedling tube, and plants were grown for 4 weeks in a $25^{\circ} \mathrm{C} / 20^{\circ} \mathrm{C}$ (day/night) growth chamber under fluorescent plant lights with a 16-h photoperiod.

Seedlings were assessed for disease based on the percentage of the root system that exhibited lesions or had collapsed. Dead plants were considered to be $100 \%$ infected. Each experiment was conducted twice.

Greenhouse experiments with chloride salts. Inoculum was prepared using a modification of the method described by Stephens and Elmer (22). Distilled water (100 ml) was added to breathable autoclave bags (Field \& Forest Products Inc., Peshtigo, WI) containing $200 \mathrm{~g}$ of pearl millet seed (Rupp Seeds). Bags were autoclaved for $1 \mathrm{~h}$ on 2 consecutive days and allowed to cool. Several pieces of silica gel infested with the isolates were added to separate bags and allowed to grow for 2 weeks. Bags were shaken occasionally to prevent clumping. Sterilized millet seed was dried in autoclaved paper bags for 7 days, then ground in a Thomas Mill (Arthur H. Thomas Co., Philadelphia, PA). Ground millet $(150 \mathrm{~g})$ infested with a mixture of $F$. oxysporum f. sp. asparagi (isolates 2-7 and FOA-50) was combined with ground millet $(150 \mathrm{~g})$ infested with a mixture of $F$. proliferatum (isolates $\mathrm{P}-67$ and $\mathrm{M}-6374$ ) and added to 40 liters of a 4:1 mixture of steamed sandy loam to Baccto High Porosity Professional Planting Mix (Michigan Peat Co., Houston, TX), to provide an inoculum density of 320,000 CFU per gram of soil. Isolate FOA-50 originating from a Michigan asparagus field and isolate M-6374 from an asparagus field in Connecticut were obtained from W. Elmer, Connecticut Agricultural Experiment Station. Soil for the uninfested control treatments consisted of a 4:1 mixture of steamed sandy loam to Baccto High Porosity Professional Planting Mix without pathogen inoculum.

Cultivar Mary Washington asparagus seeds were sterilized as previously described and germinated in the dark on sterile water agar petri plates. Seedlings were planted into $64 \mathrm{~cm}^{3}$ plug trays filled with High Porosity Professional Planting Mix (Michigan Peat Co.) as soon as hypocotyls emerged. Plants were grown for 14 days, then seedlings without lesions that were uniform in size were transferred to $512 \mathrm{~cm}^{3}$ plastic pots. The following treatments were applied to infested soil in amounts adjusted to give equivalent $\mathrm{Cl}^{-}$content in each pot: (i) no salt (control), (ii) $\mathrm{NaCl}(0.32 \mathrm{~g}$ per pot), (iii) $\mathrm{CaCl}_{2} \cdot 2 \mathrm{H}_{2} \mathrm{O}$ (0.40 g per pot), (iv) $\mathrm{NH}_{4} \mathrm{Cl}(0.29 \mathrm{~g}$ per pot), (v) $\mathrm{KCl}(0.40 \mathrm{~g}$ per pot), and (vi) $\mathrm{Mn}_{2} \mathrm{Cl} \cdot 4 \mathrm{H}_{2} \mathrm{O}$ (0.53 g per pot). An uninfested control was also included in this experiment. There were 16 replicate plants for each treatment. Plants were allowed to grow for 3 weeks and were fertilized twice weekly with $15 \mathrm{ml}$ of Hoagland's solution. Plants were watered as needed with distilled water. Treatments were arranged in a completely randomized design, and the experiment was conducted twice. Fresh weights of roots and shoots were taken, and the percentage of the root system exhibiting lesions was estimated.

$\mathrm{NaCl}$ and lime applications in established asparagus fields. A research plot $\left(688 \mathrm{~m}^{2}\right)$ was established at the Plant Pathology Research farm in East Lansing, $\mathrm{MI}$, in a 17-year-old Boyer sandy loam asparagus field (cv. Mary Washington) with severe symptoms of Fusarium-related decline, including thin stands, missing crowns, and poor fern growth. Treatments consisted of an untreated control and rock salt $(\mathrm{NaCl})$ (PureMelt Ice and Snow Melting Salt, ICM Kalium Co., Bannockburn, IL) applied at $1,120 \mathrm{~kg} / \mathrm{ha}$ on 17 April 1998, 30 April 1999, and 25 April 2000 using a Gandy drop spreader (Gandy Co., Owatonna, MN).

Treatments were arranged in a randomized complete block design with five replicates, each separated by an untreated buffer row. Treatment plots consisted of a 6.1-m section of a single row. Rows were spaced on 1.52-m centers. Pelletized lime (Nutralime, Mineral Processing Co., Carey, $\mathrm{OH})$ was applied to all treatments in the spring of each year at a rate of $6,719 \mathrm{~kg} / \mathrm{ha}$, and fertilizer (12-12-12, Northern Star Minerals, East Lansing, MI) was applied at $336 \mathrm{~kg} / \mathrm{ha}$. Pesticide sprays were applied as needed for the control of insects, weeds, and foliar diseases. Spears greater than $12.70 \mathrm{~cm}$ in height were harvested by hand snapping between 5 and 26 May 1998 (10 harvests), between 10 May and 9 June 1999 (17 harvests), and between 2 May and 6 June 2000 (14 harvests).

Two research plots were established in Oceana County, MI, in Spinks loamy fine sand asparagus fields (cv. Syn-456) in commercial production that had been previously cropped in asparagus. One plot was established in a 2.02-ha field of 11-yearold asparagus not displaying symptoms of asparagus decline. A second plot was established nearby in a 3.44-ha field of 10year-old asparagus with symptoms (thin stands, poor yields) of asparagus decline. Treatments consisted of the following: (i) an untreated control, (ii) a low rate of salt (560 kg/ha), (iii) a high rate of salt $(1,120$ $\mathrm{kg} / \mathrm{ha}$ ), (iv) a pelletized lime application $(6,718.74 \mathrm{~kg} / \mathrm{ha}),(\mathrm{v})$ a low rate of salt and pelletized lime, and (vi) a high rate of salt and pelletized lime. All treatments were applied using a Gandy drop spreader on 10 April 1998, 27 April 1999, and 19 April 2000.

Treatments were arranged in a randomized complete block design with six replicates. Treatment plots consisted of a $6.1-\mathrm{m}$ section of three rows $1.52 \mathrm{~m}$ apart. Two buffer rows separated each treatment, and $3.05 \mathrm{~m}$ separated each block within the rows. Crowns were planted approximately $25 \mathrm{~cm}$ apart in the row. Fertilizer and pesticide sprays, except for lime, were applied to these plots as needed by the growers.

All spears greater than $12.70 \mathrm{~cm}$ in height were harvested by hand snapping between 2 May and 15 June 1998 (26 harvests), 3 May and 12 June 1999 (25 and 24 harvests for the declining and healthy fields, respectively), and 2 May and 13 June and 30 April and 13 June for the declining and healthy fields, respectively, (22 harvests each) in 2000. All plots were evaluated for fern health by counting the number of stalks (excluding volunteer seedlings) greater or less than $0.79 \mathrm{~cm}$ in diameter $12.70 \mathrm{~cm}$ above the soil surface approximately 5 weeks after the termination of harvest.

Soil tests. Soil samples were taken from each treatment plot in both the experimental and commercial fields in April (before treatments were applied), July, and October 1998, in April and October 1999, and in April 2000. Eight 30.48-cm soil cores from a 20-mm sampling tube were split into 0 to $15.24 \mathrm{~cm}$ and 15.24 to $30.48 \mathrm{~cm}$ fractions and bulked. All soil samples were analyzed at the Michigan State University Soil Testing Laboratory for $\mathrm{pH}$ and for concentrations of calcium, potassium, magnesium, and sodium. Sodium levels were compared in the two fall samples (1998 and 1999) in commercial fields in order to determine whether sodium levels had increased between the 2 years.

Statistical analysis. All analyses were carried out using the Proc Mixed procedure in SAS statistical analysis software (SAS Institute, Cary, NC). Differences between treatments were determined by Least Squared (LS) means comparisons with Bonferroni adjustment factor, and were considered significant at $P<0.05$. Data on the percentage of the root system covered with lesions in the growth chamber trials with $F$. proliferatum were transformed using the arcsine square root transformation to normalize data. Because of the heterogeneous variance in trial by treatment combined data for the percentage of root system covered with lesions in the greenhouse trials, variance component estimation was carried out using the Repeated statement with Group Option in Proc Mixed. Overall treatment differences from both trials in each experiment were analyzed together unless trial by treatment interaction was found to be significant, in 
which case differences between treatments within each trial were tested. Analyses of soil test data from spring 2000 (after two treatment applications) were compared using spring 1998 data (before any treatments were applied) as a covariate. Harvest data from the 3 years were assumed repeated measures and were analyzed using the Repeated statement in Proc Mixed.

\section{RESULTS}

Growth chamber experiments with chloride salts. In two trials with $F$. proliferatum, plants treated with $\mathrm{NaCl}(57.0 \%)$ or $\mathrm{CaCl}_{2}(69.6 \%)$ had a significantly lower percentage of the root system exhibiting lesions or collapse than did control plants $(84.4 \%) . \mathrm{MnCl}_{2}(80.1 \%)$ did not significantly reduce root rot compared with the control, and had significantly more root rot than the $\mathrm{NaCl}$ treatment. $\mathrm{NH}_{4} \mathrm{Cl}(96.0 \%)$ treatments resulted in significantly more disease than the control.

Severity of root rot caused by $F$. oxysporum f. sp. asparagi was significantly less on plants treated with the high rate of $\mathrm{NaCl}(44.4 \%)$ compared with the control (77.5\%) and all the other treatments, except for the low rate of $\mathrm{NaCl}(62.3 \%)$. Neither $\mathrm{CaCl}_{2}(71.8 \%)$ nor the low rate of $\mathrm{NaCl}$ $(62.3 \%)$ significantly reduced root rot caused by this pathogen relative to the control. Plants treated with $\mathrm{NH}_{4} \mathrm{Cl}(93.6 \%)$ had significantly more root rot than the control.

Greenhouse experiments with chloride salts. Data for root weight and percentage of the root system exhibiting lesions for the trial by treatment interaction was significant, so differences between treatments within each trial were tested separately. In experiment 1 , plants treated with $\mathrm{NaCl}$ had significantly greater fresh root weight $(1.50 \mathrm{~g})$ than plants in the infested control $(0.95 \mathrm{~g})$ and in all the other treatments except $\mathrm{KCl}(1.13 \mathrm{~g})$. Fresh root weights were not significantly different among the treatments in experiment 2 . In both experiments, the uninfested control plants had significantly greater fresh root weights (4.0 and $4.4 \mathrm{~g}$ ) than all other treatments.

There were no significant differences in root rot in experiment 1 , where infection ranged from $18.6 \%(\mathrm{NaCl})$ to $47.1 \%$ $\left(\mathrm{NH}_{4} \mathrm{Cl}\right)$. In experiment 2, only plants treated with $\mathrm{NaCl}$ had significantly less root rot $(18.6 \%)$ than the infested control plants $(33.9 \%)$, but they were not significantly different from the other treatments ( 22.1 to $30.7 \%$ ). In both experiments, the uninfested control was symptomless.

Plants treated with $\mathrm{NaCl}(0.84 \mathrm{~g})$ had significantly greater fresh shoot weights than the $\mathrm{CaCl}_{2}(0.59 \mathrm{~g}), \mathrm{MnCl}_{2}(0.57 \mathrm{~g})$, and $\mathrm{NH}_{4} \mathrm{Cl}(0.48 \mathrm{~g})$ treatments, but were not greater than those treated with $\mathrm{KCl}$ $(0.68 \mathrm{~g})$ or the infested control $(0.60 \mathrm{~g})$. The uninfested control plants had significantly greater shoot weight (2.42 g) than all treatments.
$\mathrm{NaCl}$ and lime applications in established asparagus fields. Plots in the research field at the Michigan State University Plant Pathology Farm that were treated with $\mathrm{NaCl}$ had higher yields and more large ( $>0.79 \mathrm{~cm}$ diameter) stalks than untreated plots in 2000, but not in 1998 or 1999 (Fig. 1), which resulted in a significant year by treatment effect.

Treatment or year by treatment effects on asparagus yield in the commercial fields were not significant. Mean harvest weight ranged from 5,291 to $6,668 \mathrm{~g}$ in the healthy field and between 3,073 and 3,640 $\mathrm{g}$ in the declining field. Asparagus yield between years was significantly different. The treatment or year by treatment effects in the percentage of stalks larger than $0.79 \mathrm{~cm}$ in diameter were not significantly different, although significant differences between years were observed (data not shown).

Soil tests. Two applications of $\mathrm{NaCl}$ did not significantly affect levels of $\mathrm{pH}$, potassium, magnesium, or calcium in the research plot at the Michigan State University Plant Pathology Farm (data not shown). Sodium levels were significantly higher in salt-treated plots (90 and 94.6 ppm at 0 to $15 \mathrm{~cm}$ and 15 to $30 \mathrm{~cm}$, respectively) than in untreated plots (21 and 26.6 ppm at 0 to $15 \mathrm{~cm}$ and 15 to $30 \mathrm{~cm}$, respectively). Sodium levels (+35 ppm) were increased significantly in the 15 to $30 \mathrm{~cm}$, but not in the 0 to $15 \mathrm{~cm}$ soil level, between the two fall sampling periods (1998 and 1999).

In the commercial field plots in Oceana County, overall data for both fields are presented unless significant trial by treatment interactions were found between the two fields. Sodium levels between the two fall sampling periods (1998 and 1999) were not increased in the commercial fields at either soil level in any treatment (data not shown). Sodium levels in the top $15 \mathrm{~cm}$ of soil were not significantly different between the treatments in either trial (data not shown). Sodium levels in 15 to $30 \mathrm{~cm}$ of soil were significantly higher in the high $\mathrm{NaCl}(51 \mathrm{ppm})$ and high $\mathrm{NaCl}+$ lime $(56 \mathrm{ppm})$ treatments than in the other treatments. In addition, the low $\mathrm{NaCl}$ treatment had significantly higher sodium levels (36 ppm) than the control (24 ppm), lime $(24 \mathrm{ppm})$, or low $\mathrm{NaCl}+$ lime $(29$ ppm) treatments.

Magnesium, calcium, and $\mathrm{pH}$ levels were significantly affected by lime applications in the commercial fields. Differences in magnesium levels in the 0 to $15 \mathrm{~cm}$ soil level were tested separately because of significant field by treatment interactions. Magnesium levels were significantly higher in the top $15 \mathrm{~cm}$ of soil for the lime (168 ppm) and the low $\mathrm{NaCl}+$ lime (162

$\mathbf{A}$

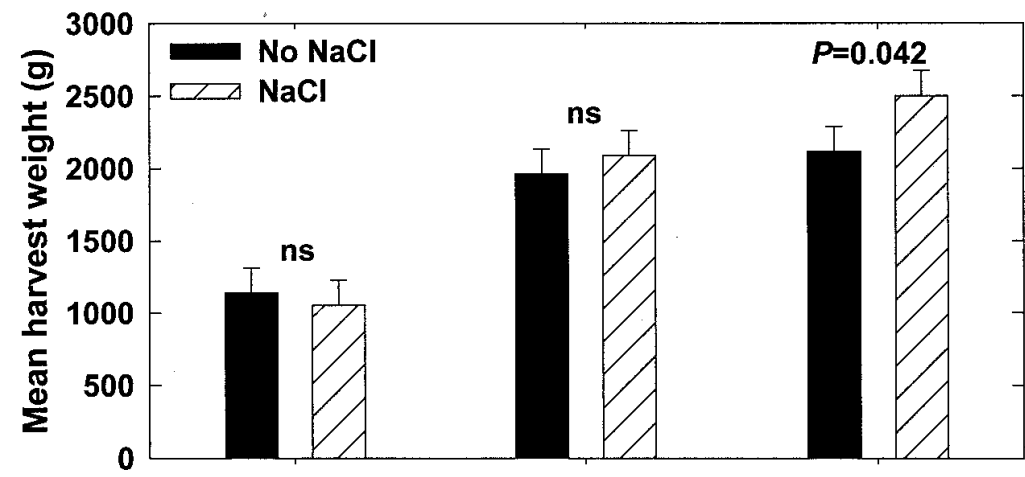

B

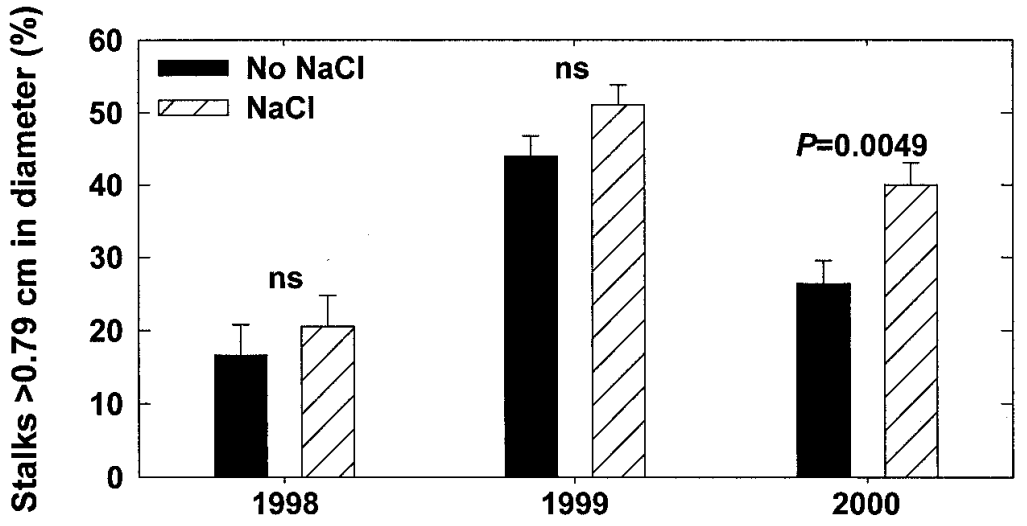

Fig. 1. Effect of sodium chloride application $(1,120 \mathrm{~kg} / \mathrm{ha})$ on $\mathbf{A}$, mean harvest weight of asparagus spears, and $\mathbf{B}$, percentage of asparagus stalks $>0.79 \mathrm{~cm}$ in diameter in research plots at the Michigan State University Plant Pathology Farm, 1998 to 2000. Error bars represent standard error. 
ppm) treatments than in the untreated control $(80 \mathrm{ppm})$ in the declining field, but were not different in the healthy field. At the 15 to $30 \mathrm{~cm}$ soil level, magnesium was significantly higher in the lime treatment (154 ppm) than in the low $\mathrm{NaCl}$ treatment (116 ppm). Calcium levels were significantly higher in the top $15 \mathrm{~cm}$ of soil in the treatments that combined low $(970 \mathrm{ppm})$ and high (979 ppm) $\mathrm{NaCl}$ levels with lime than in the low $\mathrm{NaCl}$ only treatment $(755$ ppm). Calcium levels were not different in the 15 to $30 \mathrm{~cm}$ soil level. The $\mathrm{pH}$ was significantly higher in 0 to $15 \mathrm{~cm}$ of soil when lime was applied alone (6.55) or in conjunction with high $\mathrm{NaCl}$ (6.51) compared with applications of low $\mathrm{NaCl}$ only (6.19). Similarly, at the 0 to $15 \mathrm{~cm}$ soil level, applying low $\mathrm{NaCl}+$ lime resulted in a higher $\mathrm{pH}$ (6.58) than applying low (6.19) or high (6.27) $\mathrm{NaCl}$ alone. At the 15 to $30 \mathrm{~cm}$ level, the $\mathrm{pH}$ was significantly higher (6.26) with high $\mathrm{NaCl}+$ lime than with low $\mathrm{NaCl}$ alone (6.00) or the control (5.87). Potassium levels among treatments were not significantly different at either soil level.

\section{DISCUSSION}

Yield increases associated with $\mathrm{NaCl}$ treatments are closely related to its ability to suppress Fusarium diseases, although the mechanism of disease suppression is not clearly understood $(9-12,14)$. Experiments demonstrating the ability of $\mathrm{NaCl}$ to control Fusarium crown and root rot have been conducted in research plots in Connecticut (11). Fusarium crown and root rot has become limiting to asparagus production in Michigan as growers have had to rely more on fields that have been previously cropped to asparagus. Commercial asparagus fields in Michigan are generally taken out of production once yield becomes limited by disease. In our study, $\mathrm{NaCl}$ treatments suppressed disease in a research plot at the Michigan State University Plant Pathology Farm, verifying earlier reports $(8,11)$. Treatments with $\mathrm{NaCl}$, however, did not significantly affect disease in commercial asparagus fields. The usefulness of $\mathrm{NaCl}$ treatments in limiting Fusarium crown and root rot in commercial fields has not previously been investigated. Lime applications, which decrease Fusarium diseases on other crops $(1,19)$, did not significantly affect yield or stalk diameter. Significant yield differences were found between years, but these were due to differences in the number of harvests, rainfall, and temperature.

In the commercial fields, treatment areas were separated by at least $3.05 \mathrm{~m}$ on all sides, but there was some movement of sodium from treated into untreated plots over time, especially in the lower strata of soil. Although data from soil tests seem to suggest that much of the movement occurred while the crowns were dormant, the fact that there was some salt movement into untreated plots suggests that in future tests, treated areas should be separated by a greater distance.

The effect of $\mathrm{NaCl}$ on the nutrient content and $\mathrm{pH}$ of soils, on rotation crops and groundwater, and the potential development of soil sodicity are all concerns that must be considered. Levels of magnesium, potassium, or calcium did not increase with $\mathrm{NaCl}$ applications, and salt did not affect the $\mathrm{pH}$ in our studies. Overall $\mathrm{pH}$ levels increased in both commercial fields, which may be partially explained by the fact that each of the fields was accidentally treated with a single lime application by the growers during the experiment. Analyses indicate that salt moves through the soil profile quickly in Michigan asparagus fields, and sodium did not increase in soils in commercial fields between October 1998 and October 1999. These fields have a sand content of $85 \%$ or more, and $\mathrm{NaCl}$ may leach easily through the profile with rainwater. Because there is little structure in these soils to begin with, an increase in sodicity is less of a concern than with other soil types. Bulk density of soil did not change in previous experiments with $\mathrm{NaCl}$ at these levels (11). Soil tests in the sandy loam soils in the research plots at Michigan State University indicate that salt accumulation is greater in heavier soils.

In test tube experiments, $\mathrm{NaCl}$ was more effective than other forms of chloride salt in controlling disease caused by $F$. proliferatum, and plants treated with $\mathrm{NaCl}$ had lower levels of disease caused by $F$. $o x$ ysporum f. sp. asparagi than any other treatment. Similarly, in greenhouse studies, none of the alternative chloride salts tested were more effective in controlling disease or showed greater fresh weight of roots or shoots than $\mathrm{NaCl}$ when equivalent levels of chloride were applied. In these experiments, $\mathrm{NH}_{4} \mathrm{Cl}$ increased disease symptoms.

Calcium has been shown to be important in disease resistance in some plant-disease systems by protecting pectate from maceration and ameliorating the effects of toxins (18). The increased disease suppression with $\mathrm{CaCl}_{2}$ shown in tests against $F$. proliferatum may be due to the effect of increased calcium or to an unknown disease control mechanism involving chloride. Manganese has been implicated as an important element in disease control in a number of different plant systems (18). Its inability to suppress disease in these tests may be due to its immobility at the relatively high $\mathrm{pH}$ of the agar (6.0). The increased chloride nutrition in this treatment did not affect disease incidence. It is interesting that $\mathrm{NH}_{4} \mathrm{Cl}$-treated plants had more disease than control plants in tests with both pathogens. In other systems, it has been suggested that increased nitrogen can make plants more susceptible to disease by increasing succulence and decreasing physical barriers to invasion (18). Elmer (8) has also shown that plants fertilized with ammonium nitrogen were more susceptible to disease than those fertilized with nitrate nitrogen.

Although growth chamber, greenhouse, and research plot studies did confirm that $\mathrm{NaCl}$ has the potential to decrease Fusarium disease and increase yield (10-12), $\mathrm{NaCl}$ applications in commercial fields did not reduce symptoms or increase yield in our studies. At present, applying $\mathrm{NaCl}$ to commercial asparagus fields that are still productive is not recommended in Michigan.

\section{ACKNOWLEDGMENTS}

This study was supported by funding from the Michigan Agricultural Experiment Station, Michigan State University Extension, The Michigan Department of Agriculture, The Michigan Farm Bureau (GREEEN cooperative), and Michigan asparagus growers and processors. We thank B. Cortright, W. Quackenbush, N. Myers, and J. Bakker for assistance in setup and maintenance of field plots, M. Bakker for help with data collection, and our grower-cooperators Oomen Brothers and Oomen Farms.

\section{LITERATURE CITED}

1. Bell, A. A. 1989. Role of nutrition in diseases of cotton. Pages 167-204 in: Soilborne Plant Pathogens: Management of Diseases with Macro- and Microelements. A. W. Engelhard, ed. American Phytopathological Society, St. Paul, MN.

2. Bennett, I. D. 1910. The Vegetable Garden. Doubleday, Page \& Co., New York.

3. Brady, N. C. 1990. The Nature and Properties of Soils. MacMillan Publishing Co., New York.

4. Burr, F. 1865. Field and Garden Vegetables of America. J. E. Tilton and Co., Boston.

5. Damicone, J. P., Cooley, D. R., and Manning, W. J. 1981. Benomyl in acetone eradicates Fusarium moniliforme and Fusarium oxysporum from asparagus seed. Plant Dis. 65:892-893.

6. Damicone, J. P., and Manning, W. J. 1982. Avirulent strains of Fusarium oxysporum protect asparagus seedlings from crown rot. Can. J. Plant Pathol. 4:143-146.

7. Davis, D. 1967. Cross-protection in Fusarium wilt diseases. Phytopathology 57:311-314.

8. Elmer, W. H. 1989. Effects of chloride and nitrogen form on growth of asparagus infected by Fusarium spp. Plant Dis. 73:736740 .

9. Elmer, W. H. 1990. Effect of $\mathrm{NaCl}$ on carbohydrates and malate production in asparagus roots and on infection by Fusarium. (Abstr.) Phytopathology 80:1025.

10. Elmer, W. H. 1990. Suppression of Fusarium crown and root rot of asparagus with chloride and different forms of nitrogen fertilizers. Acta Hortic. 271:323-329.

11. Elmer, W. H. 1992. Suppression of Fusarium crown and root rot of asparagus with sodium chloride. Phytopathology 82:97-104.

12. Elmer, W. H. 1995. Association between Mn-reducing root bacteria and $\mathrm{NaCl}$ applications in suppression of Fusarium crown and root rot of asparagus. Phytopathology 85:1461-1467.

13. Elmer, W. H., Johnson, D. A., and Mink, G. I. 1996. Epidemiology and management of the diseases causal to asparagus decline. Plant Dis. 80:117-125.

14. Elmer, W. H., and LaMondia, J. A. 1997. Studies on the suppression of Fusarium crown and root rot of asparagus with $\mathrm{NaCl}$. Pages 54-67 in: IX International Asparagus Symposium, Pasco, WA. B. Benson, ed. 
15. Harris, J. 1883. Gardening for Young and Old. Orange Judd Co., New York.

16. Hodupp, R. M. 1983. Investigation of factors which contribute to asparagus decline in Michigan. M.S. thesis. Michigan State University, East Lansing.

17. Huber, D. M. 1989. The role of nutrition in the take-all disease of wheat and other small grains. Pages 46-74 in: Soilborne Plant Pathogens: Management of Diseases with Macro- and Microelements. A. W. Engelhard ed. American Phytopathological Society, St. Paul, MN.

18. Huber, D. M. 1990. The use of fertilizers and organic amendments in the control of plant disease. Pages 357-394 in: Handbook of Pest Management in Agriculture. D. Pinentel, ed. CRC Press, Boca Raton, FL.

19. Jones, J. P., Engelhard, A. W., and Woltz, S. S. 1989. Management of Fusarium wilt of vegetables and ornamentals by macro- and microelement nutrition. Pages 18-32 in: Soilborne Plant Pathogens: Management of Diseases with Macro- and Microelements. A. W. Engelhard, ed. American Phytopathological Society, St. Paul, MN.

20. Lacy, M. L. 1979. Effects of chemicals on stand establishment and yields of asparagus.
Plant Dis. Rep. 63:612-616.

21. Stephens, C. T., De Vries, R. M., and Sink, K. C. 1989. Evaluation of Asparagus species for resistance to Fusarium oxysporum f. sp. asparagi and $F$. moniliforme. HortScience 24:365-368.

22. Stephens, C. T., and Elmer, W. H. 1988. An in vitro assay to evaluate sources of resistance in Asparagus spp. to Fusarium crown and root rot. Plant Dis. 72:334-337.

23. Windels, C. E., Burnes, P. M., and Kommedahl, T. 1988. Five-year preservation of Fusarium species on silica gel and soil. Phytopathology 78:107-109. 